Review Article

\section{Agaricus brasiliensis (Sun mushroom) and its therapeutic potential: A review}

\author{
Aline Mayrink de Miranda* \\ Department of Pharmaceutical Sciences, Pharmacognosy Laboratory, University of São \\ Paulo, Ribeirão Preto, Brazil
}

\section{Abstract}

In recent decades, the chemical, nutritional, and functional properties of edible mushrooms have attracted considerable attention, resulting in numerous reports on their health-associated benefits. One among such edible mushrooms, Agaricus brasiliensis, is native to Brazil and is an important food supplement. This review discusses the therapeutic potential of Agaricus brasiliensis and summarizes the current studies on this edible mushroom.

\section{More Information}

*Address for Correspondence:

Aline Mayrink de Miranda, Department of Pharmaceutical Sciences, Pharmacognosy Laboratory, University of São Paulo, Ribeirão Preto, Brazil, Email: mayrinkaline@usp.br

Submitted: December 12, 2021

Approved: January 06, 2022

Published: January 10, 2022

How to cite this article: de Miranda AM. Agaricus brasiliensis (Sun mushroom) and its therapeutic potential: A review. Arch Food Nutr Sci. 2022; 6: 006-015.

DOI: 10.29328/journal.afns.1001032

Copyright License: (C) 2022 de Miranda AM. This is an open access article distributed under the Creative Commons Attribution License, which permits unrestricted use, distribution, and reproduction in any medium, provided the original work is properly cited.

Keywords: Agaricus brasiliensis; Bioactive compound; Edible mushroom; Natural product; Pharmacological activity

Abbreviations: $A B$ : Agaricus Brasiliensis; $A B E$ : Agaricus Brasiliensis Extract; ABCG5/G8 ATP: Binding Cassette Subfamily G-Transporters; Cat: Catalase; CYP7A1: Cholesterol 7a-Hydroxylase; EDM: Experimental Diabetes Mellitus; GPX: Glutathione Peroxidase; IBD: Inflammatory Bowel Disease; LDLR: Low-Density Lipoprotein Receptor ; LPO: Lipid Peroxidation; NK: Natural Killer; NO: Nitric Oxide ; RBC: Red Blood Cell; SCFA: Short-Chain Fatty Acids; SOD: Superoxide Dismutase; SEST: Salmonella Enterica Serovar Typhimurium; STZ: Streptozotocin; TBARS: Thiobarbituric Acid Reactive Substances

(D) Check for updates

(.) OPEN ACCESS Agaricus bisporus, Boletus edulis, Agaricus blazei, Agrocybe cylindracea, and Ganoderma lucidum have been previously studied. Different antioxidants have been reported in these species including polysaccharides, ergosterol, nicotinic acid, triterpenes, and phenolic compounds [6-8]. Certain polysaccharides extracted from mushrooms can act as scavengers of superoxide and hydroxyl radicals [9].

Agaricus brasiliensis (Wasser, 2002) is also known as Agaricus blazei Murrill [10] or A. subrufescens Peck [11]. It is indigenous to Brazil where it is referred to as sun mushroom, godliness mushroom, or champignon of Brazil. The sun mushroom is a filamentous fungus classified under the Agaricaceae family, Basidiomycota division, Fungi kingdom. The cultivation of this mushroom considerably increased during the 1960s in Piedade, southwest São Paulo. Due to favorable climatic conditions, Brazil has excelled in

A. brasiliensis cultivation in the states of São Paulo, Paraná, and Minas Gerais [12,13].

The origin and scientific name of $A$. brasiliensis remains controversial $[11,14]$, and disagreements over nomenclature remain unresolved [15-17]. Thus, herein, we opted for the name Agaricus brasiliensis [14], which is presently used by most researchers. Nevertheless, the name Agaricus blazei will be maintained when referring to studies containing this taxonomic designation.

Unlike other species, A. brasiliensis grows outdoors in temperate regions with ambient temperatures ranging from $23-28 \stackrel{\circ}{\circ}$. Its height varies ranging from 10 to $15 \mathrm{~cm}$ (Figure 1 ). It develops in open, sunny fields and its fruiting bodies require light to mature. 

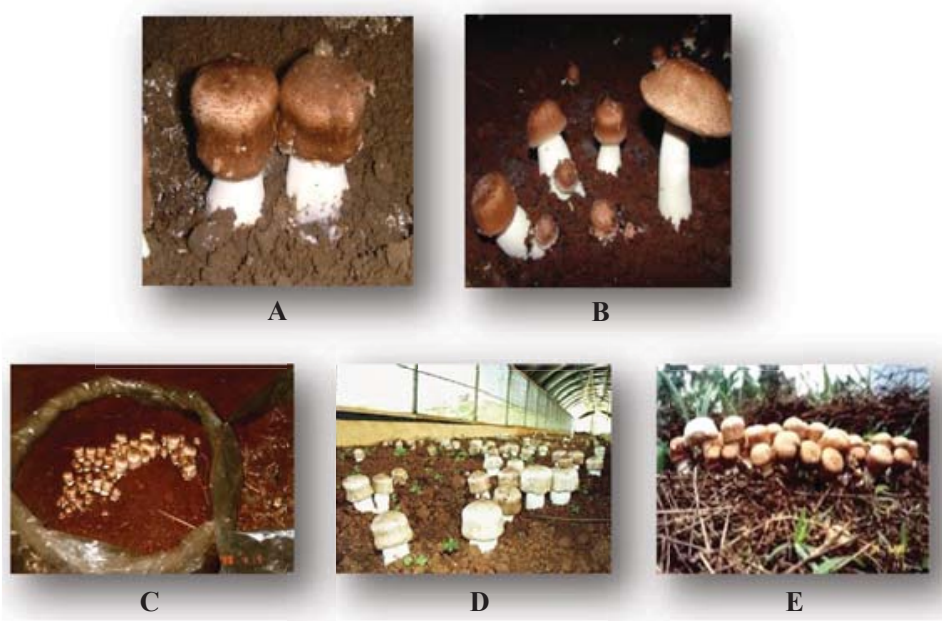

Figure 1: Agaricus brasiliensis fruiting bodies. A and B: Different stages of maturation. C: Cultivation in plastic bag. D: Protected cultivation. E: Unprotected cultivation.

Hence it is often referred to as the sun mushroom [18].

Medicinal mushrooms are an inexhaustible source of compounds with promising pharmacological activities $[19,20]$. The therapeutic potential of Agaricus brasiliensis has been reported by several studies which are reviewed here.

\section{Pharmacological activities and therapeutic potential}

In certain Asian countries, this mushroom has been widely used as a functional food or as medicine. In 2005, a study by Zhong, Tai, and Yamamoto [21] showed that its antitumor mechanism is mediated by innate and/or adaptive immunity. However, the cellular responses to this stimulus remain unclear. Rubel, et al. [22] evaluated the immunomodulatory and antitumor effects on mice fed a diet supplemented with mycelia obtained from solid-state fermentation. The Sarcoma 180 tumor growth was inhibited by consuming $A$. brasiliensis supplemented diet. The authors observed that the pattern of immune response had shifted thereby increasing CD4+ and CD8+ and decreasing CD19+ cell populations. Their results suggested that polysaccharides, such as $\beta$-glucans and other mushroom metabolites, possibly promote T-cell dominance that is imperative to restrain tumor growth. Restoring a suitable balance between cellular and humoral immunity is an essential process for restraining tumor growth [18,22].

$\beta$-glucans, polysaccharides produced by various organisms, consist of a backbone formed by linear $\beta(1 \rightarrow 3)$-, $\beta(1 \rightarrow 4)$-, or $\beta(1 \rightarrow 6)$-linked glucose molecules, which may also contain branches. The type of linkages differs among different $\beta$-glucans. $\beta$-glucans from yeast and fungi consist of $\beta(1 \rightarrow 3)$-linked glucopyranosyl units with $\beta(1 \rightarrow 6)$-linked side chains, whereas those from oat and barley are composed of unbranched $\beta(1 \rightarrow 3)$ and $\beta(1 \rightarrow 4)$ linkages. The activity of $\beta$-glucans may be influenced by their structural properties, such as polymer length, degree of branching, tertiary structure, and molecular weight. Besides the structure, the method of isolation can also affect both yield and the activity of $\beta$-glucans [23,34].
In 2005, Bernardshaw, Johnson, and Hetland [25] reported that oral administration of ABM extracts (Agaricus blazei Murrill) provided protection against systemic Streptococcus pneumoniae infection. Thus, ABM extracts could also be prophylactic and therapeutic against certain bacterial infections in humans. Original aqueous extracts of Agaricus brasiliensis did not stimulate natural killer (NK) cells. Lin, et al. [26] investigated the immunomodulatory potential of aqueous extracts of Agaricus blazei in mice with WEHI-3 leukemia.

Administration of this extract promoted NK cells and increased cancer cell phagocytosis by macrophages and monocytes.

Recently, it has been suggested that mushroom extracts could have prophylactic/therapeutic effects against pneumonic superinfection and severe lung inflammation that complicates SARS-CoV-2 infection. Several compounds have been identified in Basidiomycetes mushrooms have various therapeutic effects, including highly diversified anti-inflammatory compounds, such as polysaccharides, terpenoids, phenolic compounds, glycerides and other low molecular weight molecules [7,27]. Therapeutic benefits from administering mushroom to patients infected with SARS-CoV-2 is associated with mitigating inflammation, often referred to as "cytokine storm", observed in these patients. In addition, when mixed with two different mushroom species from Hericium and Grifola genera (H. erinaceus and G. frondosa), the sun mushroom has been shown to significantly reduce bacteremia and improve symptoms and quality of life of patients affected by other inflammatory diseases such as in inflammatory bowel disease (IBD) patients [24,28].

Di Naso, et al. [29] found that mushroom treatment reduced oxidative stress in the lungs of diabetic rats and allowed for lung tissue recovery in these animals. Niwa, et al. [30] observed that administration of Agaricus blazei extract to diabetic rats significantly suppressed spikes in fasting blood glucose and hemoglobin A1c levels. It also significantly 
mitigated the loss of body weight commonly observed in untreated diabetes. Some mushroom metabolites have efficacy against the causative protozoan of leishmaniasis and may, therefore, be therapeutic for this disease [31,32].

Several studies have demonstrated that certain mushroom species lower serum cholesterol including Grifola frondosa (Maitake), Lentinula edodes (Shiitake), Flammulina velutipes (Enokitake), Pleurotus ostreatus (Oyster mushroom), Polyporus confluens, Ganoderma lucidum (Reishi Mushroom), Auricularia auricular, Tremella fuciforms and Volvariella volvacea (straw mushroom) [20,33-38].

Most mushrooms are known to produce certain bioactive substances such as lovastatin and eritadenine. These substances were investigated as potential treatment strategies against cardiovascular diseases [39]; however, the mechanism of action of fungi extracts remains to be fully elucidated. Possible mechanisms include the reduction in serum lipid profile, increase in bile acid excretion and LDL receptor expression, change in phospholipid metabolism, and hepatic HMG-CoA reductase inhibition [40-42]. Few studies have demonstrated the cholesterollowering potential of Agaricus brasiliensis, however, the results of these reports are conflicting. In 2003, Lee and Koh evaluated the effects of liquid culture supplementation on the lipid levels in male Sprague-Dawley rats maintained on a high-fat diet. Compared to the untreated controls, animals administered $A$. blazei presented significant dose-dependent reductions in serum total cholesterol, LDL-C, and triglycerides and concomitant increases in HDL-C. Braga, et al. [43] evaluated the effects of water-based mushroom extracts on blood lipids and observed significant relative reductions only in the triglyceride and VLDL levels but not the LDL or HDL levels. Gonçalves, et al. [44] assessed the effects of ABM (5\%) extract supplementation on atherogenesis in apo-E knockout mice. This supplementation paradoxically increased the numbers and sizes of atherosclerotic lesions possibly by inducing inflammation. Meanwhile, a significant increase in the level of SR-BI receptor which participates in reverse cholesterol transport was observed in rats receiving a hypercholesterolemic diet plus 1\% Agaricus brasiliensis. These results suggest that Agaricus brasiliensis consumption improves the serum lipid profile in hypercholesterolemic rats by modulating the expression of the genes and transcription factors implicated in hepatic cholesterol metabolism [45]. These controversial results might stem from the methodological differences in route, dose, and time of administration.

Nakamura, et al. [46] used a mouse model of nonalcoholic steatohepatitis (NASH) in which pathogenesis was promoted by dietary induction. Supplementation with Agaricus brasiliensis attenuated the development of hepatic fibrosis, which is a characteristic feature of late-stage NASH. This effect appeared to be mechanistically linked to an AGApromoted reduction in hepatic oxidative stress. These results demonstrate a novel role for A. brasiliensis in NASH prevention.

\section{Functional effects of the chemical components of Agaricus brasiliensis}

$\beta$-D-glucans are a $(1 \rightarrow 3)$-linked glucose polymer with $(1 \rightarrow 6)$-linked side chains and a major component of fungal cell walls. In addition, $\beta$-glucans are widely used as adjuvant in food and pharmaceutical industries due to their physical and chemical properties [47]. The $\beta$-glucans (Figure 2) are the key chemical components of $A$. brasiliensis responsible for its cholesterol-lowering effects. According to Kim, et al. [48], since $\beta$-glucans are soluble fibers, they reduce blood cholesterol levels and glucose absorption in diabetics. The biological effects of glucans are influenced by their molecular structure. Table 1 [49] presents the chemical structures and modes of action of the various glucans, including $\beta$-glucans.

Chitin, one of the two major components with $\beta$-glucan in the fungi cell walls, has an excellent affinity for bile acids, once converted to chitosan. Neyrinck, et al. [50] demonstrated that the administration of $5 \%$ fungal chitosan from $A$. bisporus to obese mice on high-fat diets modulated lipid absorption and

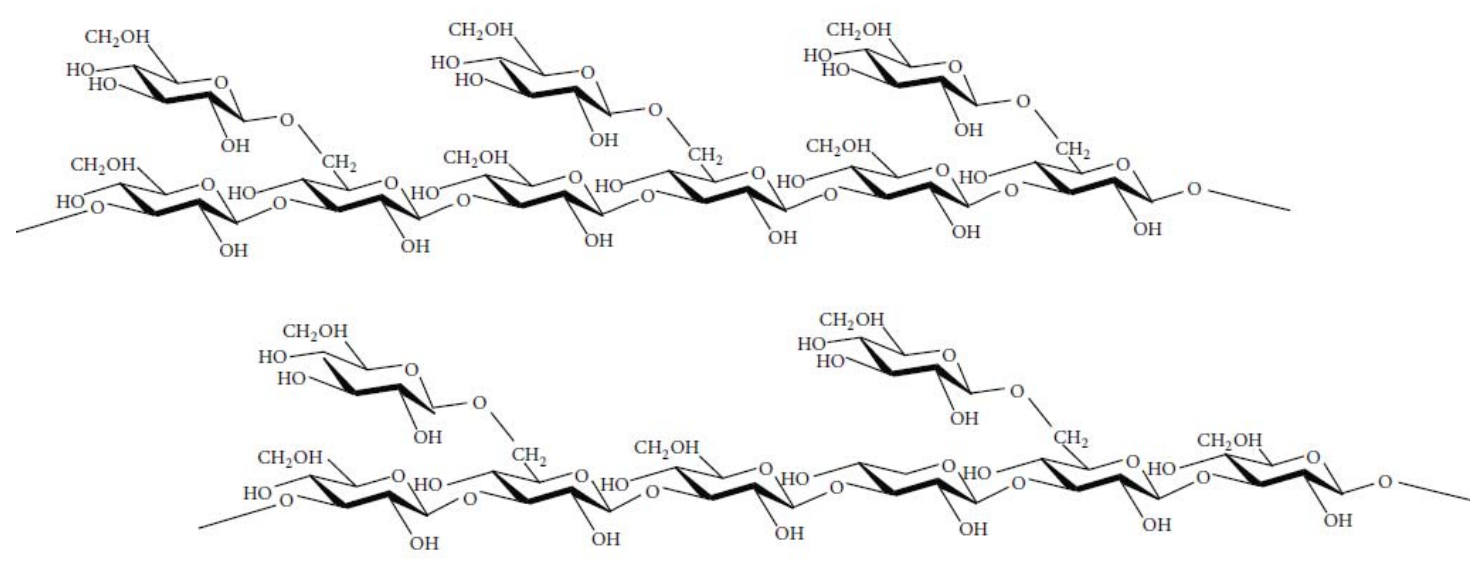




\begin{tabular}{|c|c|c|c|c|}
\hline \multirow[t]{2}{*}{ Chemical structure } & \multicolumn{2}{|c|}{ Activity reported } & \multirow[t]{2}{*}{ Mode of action } & \multirow[t]{2}{*}{ References } \\
\hline & In Vitro & In Vivo & & \\
\hline (1-6) $\beta$-glucans-protein & - & Antitumor Sarcoma 180 & - & [67-69] Mizuno et al. \\
\hline$(1-6)(1-3) \beta$-glucans & - & Antitumor Sarcoma 180 & - & [68] \\
\hline (1-6) $\beta$-glucans-protein & - & Antitumor Meth A & $\begin{array}{l}\uparrow \text { Lymphocyte } T_{\text {aux }} \\
\downarrow \text { Lymphocyte } T_{\text {supres. }}\end{array}$ & {$[70]$} \\
\hline (1-4) $\alpha$-glucans (1-6) $\beta$-glucans-protein & - & $\begin{array}{l}\text { Antimetastatic Meth } \mathrm{A} \\
\quad \text { (intratumoral) }\end{array}$ & Immunostimulation with selective cytotoxicity & [71] \\
\hline (1-4) $\alpha$-glucans (1-6) $\beta$-glucans-protein & $\begin{array}{l}\text { Tumoricidal in Meth } \mathrm{A} \\
\text { tumor cells }\end{array}$ & $\begin{array}{c}\text { Antitumor and } \\
\text { Antimetastatic Meth A }\end{array}$ & $\begin{array}{l}\text { Selective cytotoxicity, increased apoptosis } \\
\text { and NK cells }\end{array}$ & [72] \\
\hline $\begin{array}{c}(1-6)(1-3) \beta-\text { glucans and }(1-6)(1-3) \\
\beta \text {-glucans-protein }\end{array}$ & - & Antitumor Sarcoma 180 & Immunostimulation & Ohno et al. (2001) \\
\hline (1-6) (1-3) $\beta$-glucans & $\begin{array}{l}\text { Proliferation of } \mathrm{T} \\
\text { lymphocytes and B }\end{array}$ & - & - & [73] \\
\hline
\end{tabular}

reduced serum adipocytokine secretion. The latter may be associated with reduced adiposity.

Dietary fibers are classified according to their relative water solubilities, viscosities, gel formation abilities, and fermentation rates by human microbiota. Certain mechanisms have been proposed to explain the cholesterol-lowering activity of dietary fiber. Dietary fiber may decrease intestinal absorption of dietary cholesterol and lower its release via chylomicrons [51]. Dietary fiber may also promote the production of bile acids from free hepatic cholesterol [52]. The liver maintains the cholesterol pool by upregulating the LDL receptors (LDL-R) which, in turn, reduce atherogenic serum lipoprotein concentration. Fukushima, et al. [40] supplemented the diets of rats with Agaricus bisporus fibers and reported that it reduced serum total cholesterol, non-HDL cholesterol, and triglycerides and increased the mRNA levels of the hepatic LDL receptors [35,53].

Soluble fiber may undergo fermentation by bacteria in the human colon. This process generates short-chain fatty acids (SCFA) such as butyrate, propionate, and acetate which are also hypocholesterolemic [54]. Butyrate is a signaling molecule that regulates intestinal function and cholesterol metabolism by interfering with VLDL production [55]. Changes in the propionate/acetate ratio may inhibit hepatic lipogenesis [56]. Soluble fibers also promote the increase of free cholesterol concentration in the bile by activating the ABCG5 and ABCG8 carriers which belong to the ATP-binding cassette subfamily G transporters [57]. Indeed, an increased expression of $7 \alpha$-hydroxylase (CYP7A1), ATP-binding cassette subfamily G-transporters (ABCG5/G8), and lowdensity lipoprotein receptor (LDLR) was observed following diet supplementation with A. brasiliensis [45].

Mushrooms form and accumulate various secondary metabolites such as phenolic compounds, terpenes, and steroids (Table 2) [58]. Previous studies have reported that phenolic compounds inhibit intestinal absorption of dietary lipids by forming complexes with them and interfering with micellar emulsification, solubilization, and hydrolysis [59,60]. Phenolic compounds may reduce the risk of developing cardiovascular diseases by preventing hypercholesterolemia, which is the initial stage of atheromatous plaques [61,62].

The sterols in A. brasiliensis structurally resemble cholesterol and can, therefore, reduce its absorption by competitive inhibition. According to Mizuno, et al. [12], this mushroom has a large amount of ergosterol.

Over the past three decades, studies on natural compounds with an antioxidant potential have substantially increased [63]. The Table 3 summarizes the main findings about the therapeutic potential of Agaricus brasiliensis, both for studies involving animals and humans. The search for the works considered the name $A$. brasiliensis, following the classification by Wasser, et al. [14], currently, the most used by researchers. Yurkiv, et al. [64], for example, investigated the effects of the medicinal mushrooms Agaricus brasiliensis and Ganoderma lucidum on antioxidant enzyme activity in rat leukocytes.

Table 2: Bioactive compounds in the fruiting bodies of Agaricus brasiliensis with their associated pharmacological activities.

\begin{tabular}{|c|c|c|c|c|}
\hline \multirow[t]{4}{*}{ Mushroom } & Pharmacological activities & Study & Extract/Compound & References \\
\hline & $\begin{array}{l}\text { Apoptosis in leukemia cells and inhibit } \\
\text { tumor-induced angiogenesis. }\end{array}$ & In vitro & Water extracts (agaritine and ergosterol) & [74] \\
\hline & Antioxidant properties & In vitro & $\begin{array}{l}\text { Ethanolic and Hot water extracts / Phenolic } \\
\text { compounds, terpenes and steroids }\end{array}$ & [8] \\
\hline & Antibacterial and Antiparasitic & In vivo & Water extract (nd compounds) & [75] \\
\hline \multirow[t]{4}{*}{$\begin{array}{c}\text { Agaricus brasiliensis or Agaricus } \\
\text { blazei Murill }\end{array}$} & Anti-inflammatory & In vivo & Extract (?) / $\beta$-glucan (?) & Johnson et al. (2009) \\
\hline & Anti-tumor & In vivo & $\beta$-glucan, polyphenols, vitamins & [46] \\
\hline & $\begin{array}{l}\text { Cytotoxic Effect on Human Myeloma Cells and } \\
\text { Leukemic Cells }\end{array}$ & In vitro & $\begin{array}{c}\text { Extract Andosan (Agaricus blazei Murill } \\
\text { (mycelium) }(82.4 \%) \text {, Hericium erinaceus }(14.7 \%) \text {, and } \\
\text { Grifola } \\
\text { frondosa }(2.9 \%)) \text { / Proteoglycans and ergosterol }\end{array}$ & [76] \\
\hline & Inhibition HSV-1 infection & In vitro & Extracted $\beta$-glucan & [77] \\
\hline
\end{tabular}




\begin{tabular}{|c|c|c|c|c|c|c|}
\hline 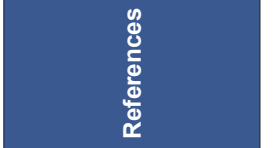 & $\stackrel{\bar{\infty}}{\triangle}$ & $\stackrel{\square}{\circ}$ & פ & 胥 & 㐫 & 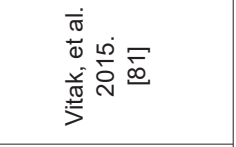 \\
\hline 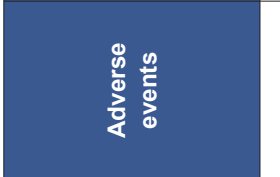 & 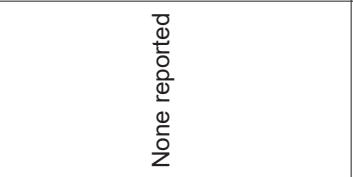 & 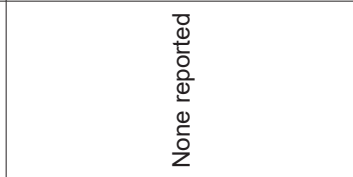 & 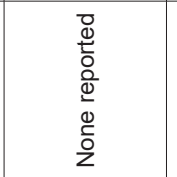 & 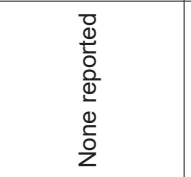 & 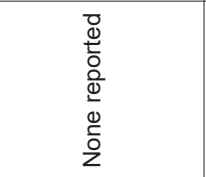 & 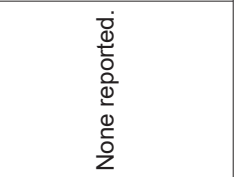 \\
\hline 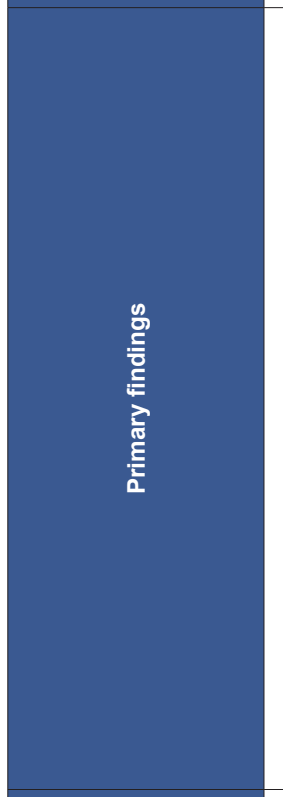 & 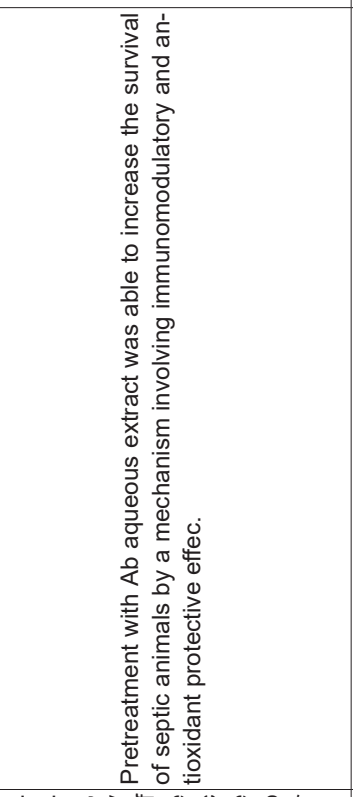 & 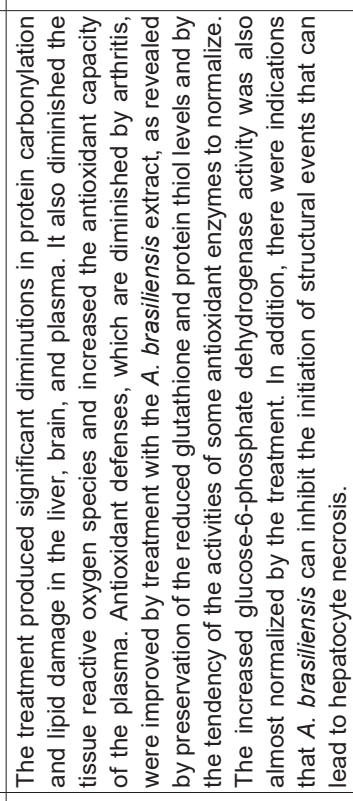 & 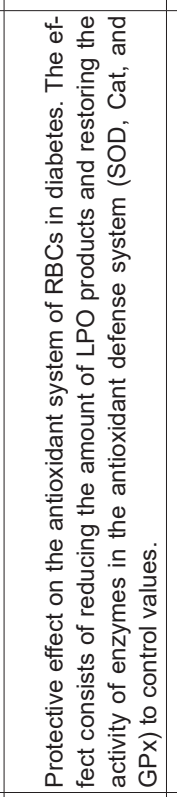 & 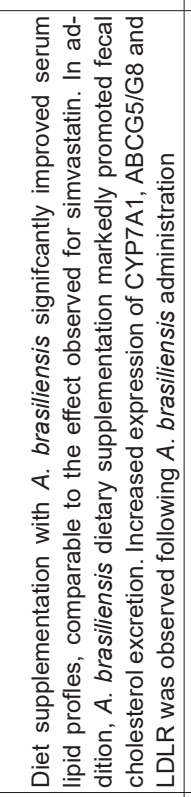 & 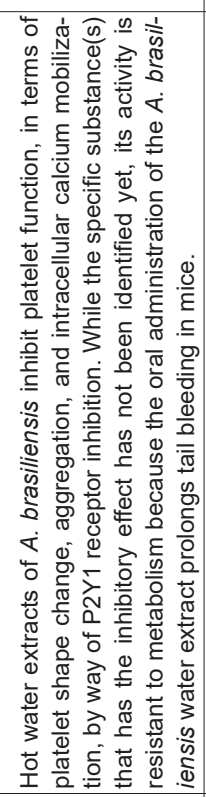 & 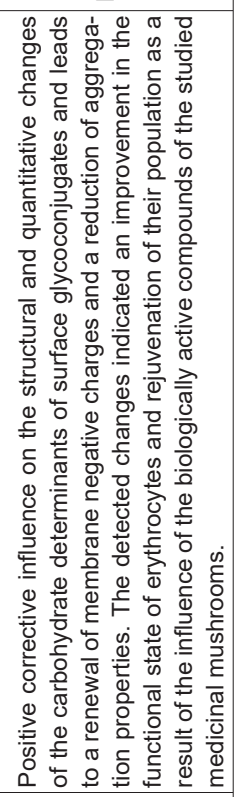 \\
\hline 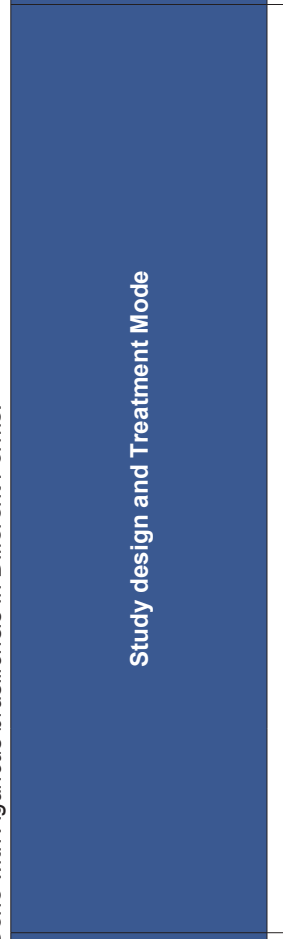 & 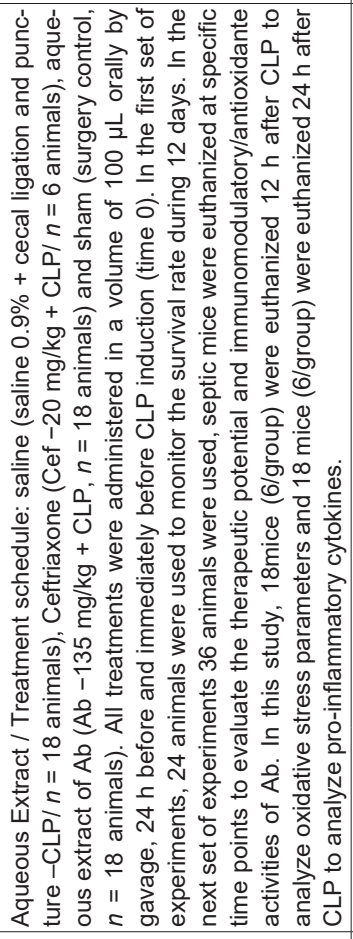 & 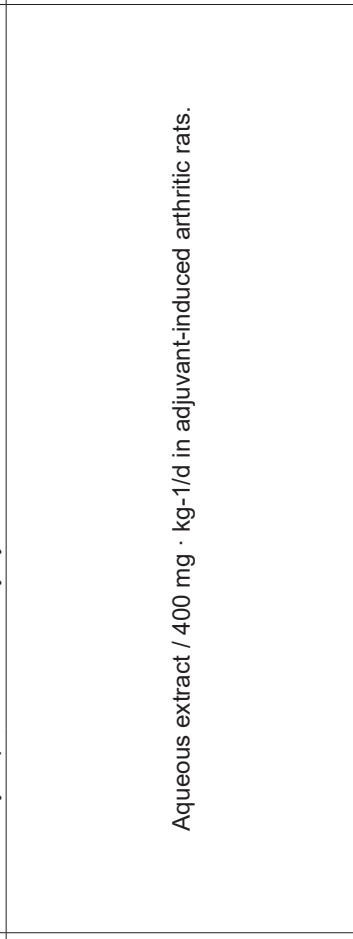 & 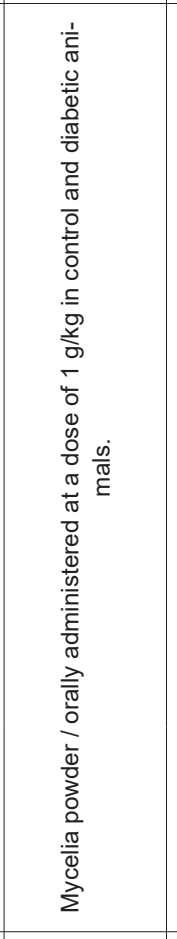 & 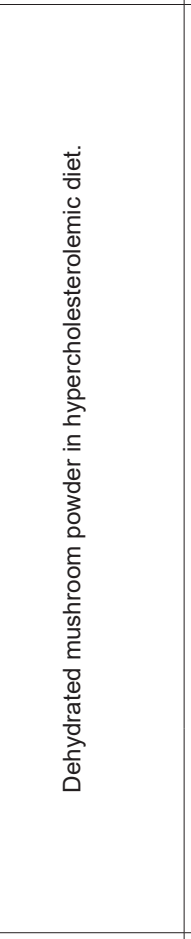 & 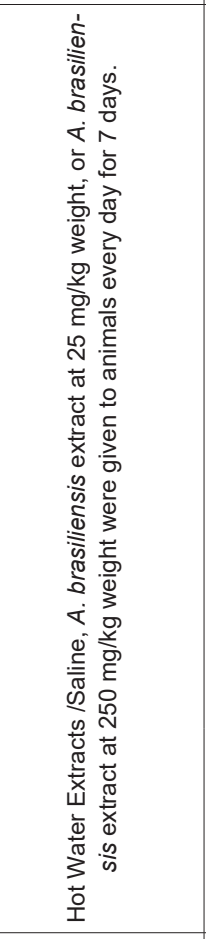 & 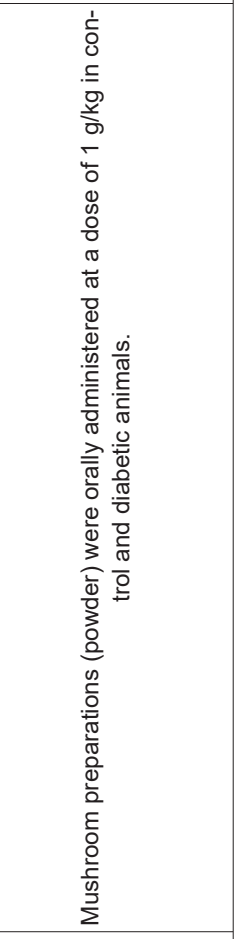 \\
\hline 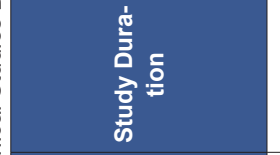 & 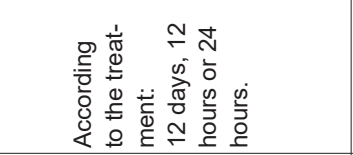 & 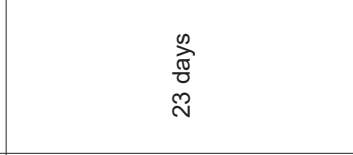 & 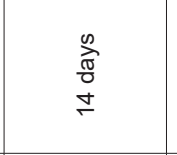 & 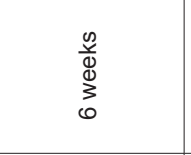 & $\begin{array}{l}\stackrel{\infty}{\frac{\pi}{0}} \\
\frac{\pi}{N}\end{array}$ & 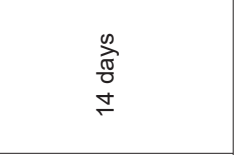 \\
\hline 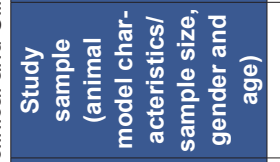 & 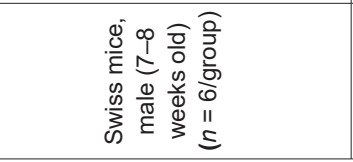 & 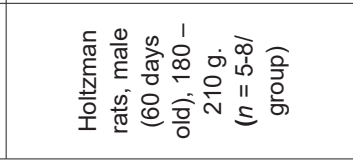 & 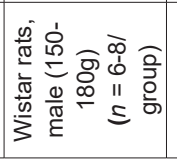 & 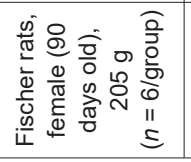 & 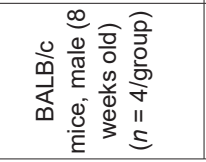 & 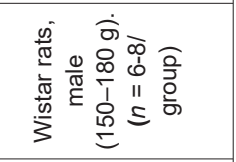 \\
\hline 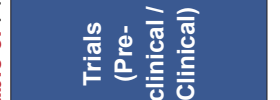 & \multicolumn{6}{|c|}{ רצכוNIרכ-כעd } \\
\hline
\end{tabular}




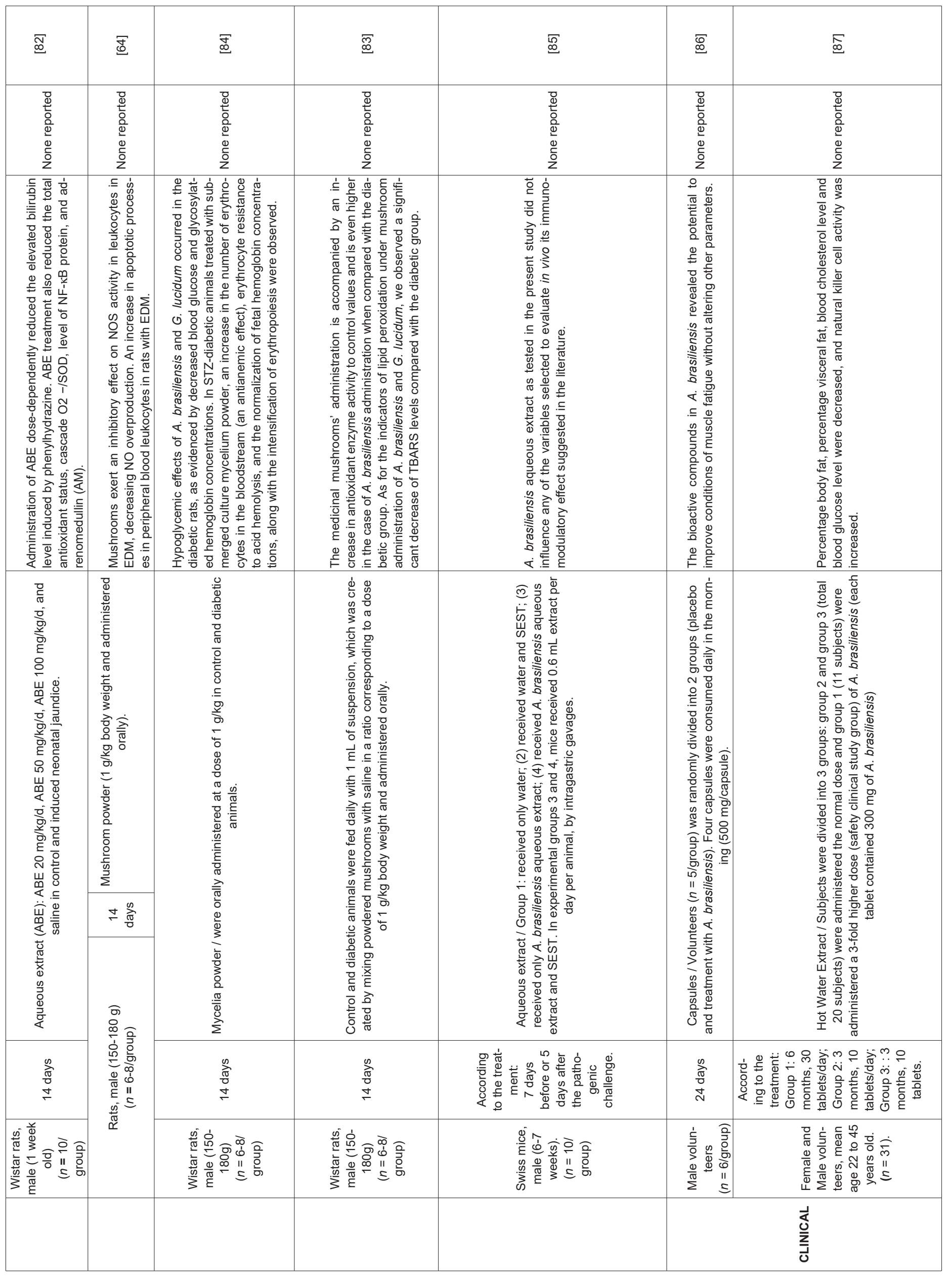


When administering $A$. brasiliensis the authors observed a significant decrease in TBARS levels compared with the diabetic group. Increased activity of antioxidant enzymes and reduction of TBARS level illustrated the antioxidant properties of these mushrooms. Tsai, et al. [8], had suggested that the antioxidant property of $A$. blazei may be associated with its high tocopherol content $[8,65]$.

De Souza, et al. [66] evaluated the effects of aqueous Agaricus brasiliensis extract on the oxidative state of the liver, brain, and plasma in adjuvant-induced arthritic rats, a model for human rheumatoid arthritis. The authors found that $A$. brasiliensis aqueous preparations can, in principle, be potential auxiliaries in the treatment of patients with rheumatoid arthritis due to their capacity to reduce oxidative stress. Data obtained suggested that the continuous ingestion of $A$. brasiliensis as specific preparations or as a food supplement can possibly help to attenuate the systemic effects of rheumatoid arthritis and improve the quality of life of patients affected by this disease.

\section{Conclusion and perspectives}

Several studies have investigated the therapeutic potential of $A$. brasiliensis, which produced empirical evidence for the antidiabetic, anticancer, antitumor, hypoallergenic, and hypocholesterolemic activity of this species. Moreover, the sun mushroom is considered a major source of bioactive compounds with potential health benefits. Its $\beta$-glucan and phenolic compound content along with its high protein and low lipid content contribute to its therapeutic potential. Whether these effects are associated with a specific component or a synergistic effect remains to be determined. New studies are being conducted to elucidate the exact mechanism and the possible components involved in its therapeutic effect.

\section{References}

1. Loguercio-leite C, Groposo C, Dreschler-Santos ER, de F Figueiredo N, da S. Godinho P, et al. A particularidade de ser um fungo - constituintes celulares. Biotemas. 2006; 19: 17-27.

2. Chang ST. A global strategy for the bioconversion of lignocellulosic biomass - a challenge of a "Non-green Revolution". 1998. https://www. zeri.uniosnabruek.de./nongreeneng.htm

3. Gao Y, Lan J, Dai X, Ye J, Zhou S, et al. A phase I/Il study of Ling Zhi Mushroom Ganoderma lucidum (W. Curt.: Fr) Lloyd (Aphyllophoromycetideae) Extract in patients with type II diabetes mellitus. Int J Med Mushrooms. 2004; 6: 1.

4. Kodama N, Murata Y, Asakawa A, Inui A, Hayashi M, et al. Maitake D-Fraction enhances antitumor effects and reduces immunosuppression by mitomycin- $C$ in tumor bearing mice. Nutrition. 2005; 21: 624-629. PubMed: https://pubmed.ncbi.nlm.nih.gov/15850970/

5. Yu CH, Kan SF, Shu CH, Lu TJ, Lucy SH, et al. Inhibitory mechanisms of Agaricus blazei Murill on the growth of prostate cancer in vitro and in vivo. J Nutr Biochem. 2009; 20: 753-764.

PubMed: https://pubmed.ncbi.nlm.nih.gov/18926679/

6. Savoie JM, Minvielle N, Largeteau LM. Radical-scavenging properties of extracts from the white button mushroom Agaricus bisporus. J Sci Food Agri. 2008; 88: 970-975.
7. Song HH, Chae HS, Oh SR, Lee HK, Chin YW. Anti-inflammatory and anti-allergic effect of Agaricus blazei extract in bone marrow-derived mast cells. Am J Chin Med. 2012; 40: 1073-1084.

PubMed: https://pubmed.ncbi.nlm.nih.gov/22928836/

8. Tsai SY, Tsai HL, Mau JL. Antioxidant properties of Agaricus blazei, Agrocybe cylindracea, and Boletus edulis. LWT Food Sci. Technol. 2007; 40: 1392-1402.

9. Mau JL, Lin HC, Chen ST. Antioxidant properties of several medicinal ushroom. J Agri Food Chem. 2002; 50: 6072-6077.

PubMed: https://pubmed.ncbi.nlm.nih.gov/12358482/

10. Heinemann P. Agaricaceae des regions intertropicales d'Amerique du Sud: Agarici Austroamericani VII. Boll. Jard Bot Natl Belg. 1993; 62:355-384

11. Kerrigan RW. Agaricus subrufescens, a cultivated edible and medicinal mushroom, and its synonyms. Mycologia. 2005; 97: 12-24. PubMed: https://pubmed.ncbi.nlm.nih.gov/16389952/

12. Mizuno T, Sakai T, Chihara, G. Health foods and medicinal usages of mushrooms. Food Rev Int. 1995; 11: 69-81.

13. Dias ES. Mushroom cultivation in Brazil: challenges and potential for growth. Ciência e Agrotecnologia. 2010; 34: 795-803.

14. Wasser SP. Medicinal mushrooms as a source of antitumor and immunomodulating polysaccharides. Appl Microbiol Biotechnol. 2002; 60: 258-274

PubMed: https://pubmed.ncbi.nlm.nih.gov/12436306/

15. Kerrigan RW. Inclusive and Exclusive Concepts of Agaricus Subrufescens Peck: a Reply to Kerrigan RW. Int J Med Mushrooms. 2007; 9: 79-84.

16. Wasser SP. Is a widely cultivated culinary-medicinal Royal Sun Agaricus (Champignon do Brazil, or the Himematsutake mushroom) Agaricus brasiliensis indeed a synonym of A. subrufescens Peck? Int J Med Mushrooms. 2005; 7: 507-511.

17. Wasser SP. Molecular identification of species of the genus Agaricus. Why should we look at morphology? Int J Med Mushrooms. 2007; 9 : 85-88.

18. Borzacchini O. Agaricus (ABM): general info. 2008. http://www altcancer.com/agaricus.htm

19. Ayeka PA. Potential of mushroom compounds as immunomodulators in cancer immunotherapy: a review. Evid Based Complement. Alternat Med. 2018; 2018: 7271509.

PubMed: https://pubmed.ncbi.nlm.nih.gov/29849725/

20. Berger A, Rein D, Kratky K, Monnard I, Hajjaj H, et al. Cholesterollowering properties of Ganoderma lucidum in vitro, ex vivo, and in hamsters and minipigs. Lipids Health Dis. 2004; 3: 2. PubMed: https://pubmed.ncbi.nlm.nih.gov/14969592/

21. Zhong M, Tai $\mathrm{A}$, Yamamoto I. In vitro augmentation of natural killer activity and interferon- $\gamma$ production in murine spleen cells with $A$. blazei fruiting body fractions. Biosci Biotechnol Biochem. 2005; 69: 2466-2469. PubMed: https://pubmed.ncbi.nlm.nih.gov/16377912/

22. Rubel R, Santa HSD, Dos Santos LF, Fernandes LC, Figueiredo BC et al. Immunomodulatory and antitumoral properties of Ganoderma lucidum and agaricus brasiliensis (Agaricomycetes) medicinal mushrooms. Int J Med Mushrooms. 2018; 20: 393-403.

PubMed: https://pubmed.ncbi.nlm.nih.gov/29953399/

23. Brown GD, Herre J, Williams DL, Willment JA, Marshall ASJ, et al. Dectin-1 mediates the biological effects of beta-glucans. J Exp Med. 2003; 197: 1119-1124.

PubMed: https://pubmed.ncbi.nlm.nih.gov/12719478/

24. Hetland G, Johnson E, Bernardshaw SV, Grinde B. Can medicinal mushrooms have prophylactic or therapeutic effect against COVID-19 and its pneumonic superinfection and complicating inflammation? Scand. J Immunol. 2020; e12937.

PubMed: https://pubmed.ncbi.nIm.nih.gov/32657436/ 
25. Bernardshaw S, Johnson E, Hetland G. An extract of the mushroom Agaricus blazei Murill administered orally protects against systemic Streptococcus pneumoniae infection in mice. Scand J Immunol. 2005; 62: 393-398.

PubMed: https://pubmed.ncbi.nlm.nih.gov/16253127/

26. Lin JG, Fan MJ, Tang NY, Yang JS, Hsia TC, et al. An extract of Agaricus blazei Murrill administered orally promotes immune responses in murine leukemia BALB/c mice in vivo. Integr. Cancer Ther. 2012; 11: 29-36. PubMed: https://pubmed.ncbi.nlm.nih.gov/22637937/

27. Wasser SP, Weis AL. Therapeutic effects of substances occurring in higher Basidiomycetes mushrooms: a modern perspective. Crit Rev Immunol. 1999; 19: 65-96.

PubMed: https://pubmed.ncbi.nlm.nih.gov/9987601/

28. Therkelsen SP, Hetland G, Lyberg T, Lygren I, Johnson E. Effect of a Medicinal Agaricus blazei Murill-Based Mushroom Extract, AndoSan ${ }^{\mathrm{TM}}$, on Symptoms, Fatigue and Quality of Life in Patients with Ulcerative Colitis in a Randomized Single-Blinded Placebo Controlled Study. Plos One. 2016; 11, e0150191.

PubMed: https://pubmed.ncbi.nlm.nih.gov/26933886/

29. Di Naso FC. Effect of Agaricus blazei Murill on the pulmonary tissue of animals with streptozotocin-induced diabetes. Exp Diabetes Res. 2010; 543926.

PubMed: https://pubmed.ncbi.nlm.nih.gov/20585363/

30. Niwa A, Tajiri T, Higashino H. Ipomoea batatas and Agarics blazei ameliorate diabetic disorders with therapeutic antioxidant potential in streptozotocin-induced diabetic rats. J Clin Biochem Nutr. 2011; 48 194-202

PubMed: https://pubmed.ncbi.nlm.nih.gov/21562638/

31. De Jesus Pereira NC, Régis WCB, Costa LE, de Oliveira JS, da Silva AG, et al. Evaluation of adjuvant activity of fractions derived from Agaricus blazei, when in association with the recombinant LiHyp1 protein, to protectagainstvisceral leishmaniasis. Exp Parasitol. 2015; 153:180-190. PubMed: https://pubmed.ncbi.nlm.nih.gov/25845753/

32. Valadares DG, Duarte MC, Ramírez L, Chávez-Fumagalli MA, Martins VT, et al. Prophylactic or therapeutic administration of Agaricus blazei Murrill is effective in treatment of murine visceral leishmaniasis. Exp Parasitol. 2012; 132: 228-236.

PubMed: https://pubmed.ncbi.nlm.nih.gov/22824583/

33. Bobek P, Ozdín L, Galbavý S. Dose- and time-dependent hypocholesterolemic effect of oyster mushroom (Pleurotus ostreatus) in rats. Nutrition. 1998; 14: 282-286.

PubMed: https://pubmed.ncbi.nlm.nih.gov/9583372/

34. Cheung PC. Plasma and hepatic cholesterol levels and fecal neutral sterol excretion are altered in hamsters fed straw mushroom diets. J Nutr. 1998; 128: 1512-1516.

PubMed: https://pubmed.ncbi.nlm.nih.gov/9732312/

35. Fukushima M, Ohashi T, Fujiwara Y, Sonoyama K, Nakano M Cholesterol-lowering effects of maitake (Grifola frondosa) fiber, shiitake (Lentinus edodes) fiber, and enokitake (Flammulina velutipes) fiber in rats. Exp Biol Med. 2001; 226, 758-765.

PubMed: https://pubmed.ncbi.nlm.nih.gov/11520942/

36. Kubo K, Nanba H. Anti-hyperliposis effect of maitake fruit body (Grifola frondosa). I Biol Pharm Bull. 1997; 20: 781-785.

PubMed: https://pubmed.ncbi.nlm.nih.gov/9255420/

37. Sugiyama K. Hypocholesterolemic activity of ningyoutake (Polyporus confluens) mushroom in rats. Nihon Eiyou Shokuryou Gakkaishi. 1992; 45: $265-270$

38. Yang H, Hwang I, Kim S, Hong EJ, Jeung EB, et al. Lentinus edodes promote fat removal in hypercholesterolemic mice. Exp Ther Med. 2013; 6: 1409-1413.

PubMed: https://pubmed.ncbi.nlm.nih.gov/24255670/

39. Guillamón E, García-Lafuente A, Lozano M, D’Arrigo M, Rostagno MA et al. Edible mushrooms: role in the prevention of cardiovascular diseases. Fitoterapia. 2010; 81: 715-723.

PubMed: https://pubmed.ncbi.nlm.nih.gov/20550954/

40. Fukushima M, Nakano M, Y Morii, T Ohashi, Y Fujiwara, et al. Hepatic LDL receptor mRNA in rats is increased by dietary mushroom (Agaricus bisporus) fiber and sugar beet fiber. J Nutr. 2000; 130: 2151-2156. PubMed: https://pubmed.ncbi.nlm.nih.gov/10958806/

41. Hu SH, Liang ZC, Chia YC, Lien JL, Chen KS, et al. Antihyperlipidemic and antioxidant effects of extracts from Pleurotus citrinopileatus. J Agric Food Chem. 2006; 54: 2103-2110.

PubMed: https://pubmed.ncbi.nlm.nih.gov/16536582/

42. Khatun K, Mahtab H, Khanam PA, Sayeed MA, Khan KA, et al. Oyster mushroom reduced blood glucose and cholesterol in diabetic subjects. Mymensingh Med J. 2007; 16: 94-99.

PubMed: https://pubmed.ncbi.nlm.nih.gov/17344789/

43. Braga LH. Avaliação dos efeitos da utilização do Agaricus blazei Murri sobre os índices de LDL, HDL, VLDL e triglicerídeos em ratos Wistar, in: de Pesquisa de les do Sistema E. Estadual de Minas Gerais, U. Caratinga/MG, III. 2008.

44. Gonçalves JL, Roma EH, Gomes-Santos AC, Aguilar EC, Cisalpino D, et al. Pro-inflammatory effects of the mushroom Agaricus blazei and its consequences on atherosclerosis development. Eur J Nutr. 2012; 51 : 927-937.

PubMed: https://pubmed.ncbi.nlm.nih.gov/22086299/

45. De Miranda AM. Agaricus brasiliensis (sun mushroom) affects the expression of genes related to cholesterol homeostasis. Eur J Nutr. 2017; 56: 1707-1717.

PubMed: https://pubmed.ncbi.nlm.nih.gov/27151383/

46. Nakamura A, ZhuQ, Yokoyama Y, Kitamura N, Uchida S, et al Agaricus brasiliensis KA21 may prevent diet-induced Nash through its antioxidant, anti-inflammatory, and anti-fibrotic activities in the liver. Foods. 2019; 8: 546.

PubMed: https://www.ncbi.nlm.nih.gov/pmc/articles/PMC6915480/

47. Borchani C, Fonteyn F, Jamin G, Destain J, Willems L, et al. Structural Characterization, Technological Functionality, and Physiological Aspects of Fungal $\beta$-D-glucans: a review. Crit. Rev. Food Sci Nutr. 2016; 56: 1746-1752

PubMed: https://pubmed.ncbi.nlm.nih.gov/25830657/

48. Kim YW, Kim KH, Choi HJ, Lee DS. Anti-diabetic activity of $\beta$-glucans and their enzymatically hydrolyzed oligosaccharides from Agaricus blazei. Biotechnol. Lett. 2005; 27: 483-487.

PubMed: https://pubmed.ncbi.nlm.nih.gov/15928854/

49. Camelini.

50. Neyrinck AM, Bindels LB, De Backer F, Pachikian BD, Cani PD, et al Dietary supplementation with chitosan derived from mushrooms changes adipocytokine profile in diet-induced obese mice, a phenomenon linked to its lipidlowering action. Int Immunopharmacol. 2009; 9: 767-773. PubMed: https://pubmed.ncbi.nlm.nih.gov/19286482/

51. Fernandez ML. Soluble fiber and nondigestible carbohydrate effects on plasma lipids and cardiovascular risk. Curr Opin Lipidol. 2001; 12: 35-40. PubMed: https://pubmed.ncbi.nlm.nih.gov/11176201/

52. Van Bennekum AM, Nguyen DV, Schulthess G, Hauser H, Phillips MC Mechanisms of cholesterol-lowering effects of dietary insoluble fibres: relationships with intestinal and hepatic cholesterol parameters. $\mathrm{Br} \mathrm{J}$ Nutr. 2005; 94L: 331-337.

PubMed: https://pubmed.ncbi.nlm.nih.gov/16176602/

53. Fernandez ML. Distinct mechanisms of plasma LDL lowering by dietary fiber in the guinea pig: specific effects of pectin, guar gum, and psyllium. J Lipid Res. 1995; 36: 2394-2404.

PubMed: https://pubmed.ncbi.nlm.nih.gov/8656077/

54. Chen ZY, Jiao R, Ma KY. Cholesterol-lowering nutraceuticals and functional foods. J Agric Food Chem. 2008; 56: 8761-8773.

PubMed: https://pubmed.ncbi.nlm.nih.gov/18778072/ 
55. Marcil V, Delvin E, Seidman F, Poitras L, Zoltowska M, et al. Modulation of lipid synthesis, apolipoprotein biogenesis, and lipoprotein assembly by butyrate. Am J Physiol Gastrointest Liver Physiol. 2002; 283: G340-G346.

PubMed: https://pubmed.ncbi.nlm.nih.gov/12121881/

56. Theuwissen E, Mensink RP. Water-soluble dietary fibers and cardiovascular disease. Physiol Behav. 2008; 94: 285-292.

PubMed: https://pubmed.ncbi.nlm.nih.gov/18302966/

57. Rideout TC, Fan MZ. Guar gum consumption enhances hepatic ABCG5/G8 expression and increases ileal cholesterol excretion in pigs. Vasc Health Risk Manag. 2008; 4: 1023-1033.

PubMed: https://www.ncbi.nlm.nih.gov/pmc/articles/PMC2605338/

58. Turkoglu A, et al. Antioxidant and antimicrobial activities of Laetiporus sulphureus (Bull.) Murrill Food Chem. 2007; 101: 267-273.

59. Bose M, Lambert JD, Ju J, Reuhl KR, Shapses SA, et al. The major green tea polyphenol, (-)-epigallocatechin-3-gallate, inhibits obesity, metabolic syndrome, and fatty liver disease in high-fat-fed mice. J Nutr. 2008; 138: 1677-1683.

PubMed: https://pubmed.ncbi.nlm.nih.gov/18716169/

60. Naissides M, Mamo JCL, James AP, Pal S. The effect of acute red wine polyphenol consumption on postprandial lipaemia in postmenopausal women. Atherosclerosis. 2004; 177: 401-408.

PubMed: https://pubmed.ncbi.nlm.nih.gov/15530916/

61. Kobayashi S. The effect of polyphenols on hypercholesterolemia through inhibiting the transport and expression of Niemann-Pick C1Like 1. Int J Mol Sci. 2019; 20: 4939.

PubMed: https://pubmed.ncbi.nlm.nih.gov/31590417/

62. Lutz M, Fuentes E, Ávila F, Alarcón M, Palomo I. Roles of phenolic compounds in the reduction of risk factors of cardiovascular diseases. Molecules. 2019; 24: 366.

PubMed: https://pubmed.ncbi.nlm.nih.gov/30669612/

63. Oyetayo VO. Free radical scavenging and antimicrobial propertiers of extracts of wild mushrooms. Br J Microbiol. 2009; 40: 380-386. PubMed: https://pubmed.ncbi.nlm.nih.gov/24031376/

64. Yurkiv B, Wasser SP, Nevo E, Sybirna NO. Antioxidant effects of medicinal mushrooms agaricus brasiliensis and Ganoderma lucidum (higher basidiomycetes): evidence from animal studies. Int $\mathrm{J}$ Med Mushrooms. 2015; 17: 943-955.

PubMed: https://pubmed.ncbi.nlm.nih.gov/26756186/

65. Oliveira OMMF, Vellosa JCR, Fernandes AS, Buffa-Filho W, HakimeSilva RA, et al. Antioxidant activity of Agaricus blazei. Fitoterapia. 2007; 78: 263-264.

PubMed: https://pubmed.ncbi.nlm.nih.gov/17349751/

66. da Silva de Souza AC, de Almeida Goncalves G, Soares AA, de Sá-Nakanishi AB, de Santi-Rampazzo AP, et al. Antioxidant action of an aqueous extract of royal sun medicinal mushroom, Agaricus brasiliensis (Agaricomycetes), in Rats with Adjuvant-Induced Arthritis. Int J Med Mushrooms. 2018; 20: 101-117.

PubMed: https://pubmed.ncbi.nlm.nih.gov/29773003/

67. Kawagishi $H$. Formolysis of a potent antitumor $(1 \rightarrow 6)-\beta-D-$ glucanprotein complex from Agaricus blazei fruiting bodies and antitumor activity of the resulting products. Carbohydr Polym. 1980; 12: 393-403.

68. Mizuno T. Antitumor activity and some properties of water-soluble polysaccides from "Himematsutake", the fruiting body of Agaricus blazei Murill. Agric Biol Chem. 1990a; 54: 2889-2896.

69. Mizuno T. Antitumor activity and some properties of water-insoluble polysaccharides from "Himematsutake", the fruiting body of Agaricus blazei Murill. Agric Biol Chem. 1990b; 54: 2897-2905.

70. Itoh $\mathrm{H}$, Ito $\mathrm{H}$, Amano $\mathrm{H}$, Noda $\mathrm{H}$. Inhibitory action of a $(1 \rightarrow 6)-\beta-\mathrm{D}$ glucan-protein complex (FIII-2-b) isolated from Agaricus blazei Muril ("Himematsutake") on Meth A fibrosarcoma-bearing mice and its antitumor mechanism. Jpn J Pharmacol. 1994; 66: 265-271. PubMed: https://pubmed.ncbi.nlm.nih.gov/7869611/
71. Ebina T, Fujimiya Y. Antitumor effect of a peptide-glucan preparation extracted from Agaricus blazei in a double-grafted tumor system in mice. Biotherapy. 1998; 11: 259-265.

PubMed: https://pubmed.ncbi.nlm.nih.gov/9950102/

72. Fujimiya $\mathrm{Y}$, Suzuki $\mathrm{Y}$, Oshiman $\mathrm{K}$, Kobori $\mathrm{H}$, Moriguchi $\mathrm{K}$, et al. Selective tumoricidal effect of soluble proteoglucan extracted from the basidiomycete, Agaricus blazei Murill, mediated via natural killer cell activation and apoptosis. Cancer Immunol. Immunother. 1998; 46: 147-159.

PubMed: https://pubmed.ncbi.nlm.nih.gov/9625538/

73. Dong Q, Yao J, Yang X, Fang J. Structural characterization of a water-soluble $\beta$-D-glucan from fruiting bodies of Agaricus blazei Murr. Carbohydr Res. 2002; 337: 1417-1421.

PubMed: https://pubmed.ncbi.nlm.nih.gov/12204626/

74. Sorimachi K, Akimoto K, Ikehara Y, Inafuku K, Okubo A, et al. Secretion of TNF- $\alpha$, IL-8 and nitric oxide by macrophages activated with Agaricus blazei Murill fractions in vitro. Cell Struct Funct. 2001; 26: 103-108. PubMed: https://pubmed.ncbi.nlm.nih.gov/11482452/

75. Bernardshaw S, Hetland G, Ellertsen LK, Tryggestad AMA, Johnson E. An extract of the medicinal mushroom Agaricus blazei muril differentially stimulates production of pro-inflammatory cytokines in human monocytes and human vein endothelial cells in vitro. Inflammation. 2005; 29: 147-153.

PubMed: https://pubmed.ncbi.nlm.nih.gov/17091395/

76. Tangen JM, Holien T, Mirlashari MR, Misund K, Hetland G. Cytotoxic Effect on Human myeloma Cells and leukemic Cells by the Agaricus blazei Murill Based Mushroom Extract, Andosan ${ }^{\mathrm{TM}}$. BioMed Res. Int. 2017; 2059825.

PubMed: https://pubmed.ncbi.nlm.nih.gov/29238712/

77. Minari MC, Rincão VP, Soares SA, Ricardo NM, Nozawa C, et al. Antiviral properties of polysaccharides from Agaricus brasiliensis in the replication of bovine herpesvirus 1. Acta Virol. 2011; 55: 255-259. PubMed: https://pubmed.ncbi.nlm.nih.gov/21978159/

78. Navegantes-Lima KC, Monteiro VVS, de França Gaspar SL, de Brito Oliveira AL, de Oliveira JP, et al. Agaricus brasiliensis Mushroom Protects Against Sepsis by Alleviating Oxidative and Inflammatory Response. Front Immunol. 2020; 11: 1238. PubMed: https://pubmed.ncbi.nlm.nih.gov/32714320/

79. Vitak TY, Wasser SP, Nevo E, Sybirna NO. Enzymatic System of Antioxidant Protection of Erythrocytes in Diabetic Rats Treated with Medicinal Mushrooms Agaricus brasiliensis and Ganoderma lucidum (Agaricomycetes). Int J Med Mushrooms. 2017; 19: 697-708.

PubMed: https://pubmed.ncbi.nlm.nih.gov/29199569/

80. Akahane K, Satoh K, Ohta M, Ozaki Y. Hot Water Extracts of the Royal Sun Mushroom, Agaricus brasiliensis (Higher Basidiomycetes), Inhibit Platelet Activation via the P2Y1 Receptor. Int J Med Mushrooms. 2015; 17: 763-770.

PubMed: https://pubmed.ncbi.nlm.nih.gov/26559862/

81. Vitak TY, Wasser SP, Nevo E, Sybirna NO. Structural Changes of Erythrocyte Surface Glycoconjugates after Treatment with Medicinal Mushrooms. Int J Med Mushrooms. 2015; 17: 867-878. PubMed: https://pubmed.ncbi.nlm.nih.gov/26756299/

82. Zhang L, Yuan B, Wang HP, Gao Y. Therapeutic effect of Agaricus brasiliensis on phenylhydrazine-induced neonatal jaundice in rats. Biomed Res Int. 2015; 2015: 651218. PubMed: https://pubmed.ncbi.nlm.nih.gov/25883968/

83. Yurkiv B, Wasser SP, Nevo E, Sybirna NO. The Effect of Agaricus brasiliensis and Ganoderma lucidum Medicinal Mushroom Administration on the L-arginine/Nitric Oxide System and Rat Leukocyte Apoptosis in Experimental Type 1 Diabetes Mellitus. Int J Med Mushrooms. 2015; 17: 339-350.

PubMed: https://pubmed.ncbi.nlm.nih.gov/25954960/

84. Vitak TY, Wasser SP, Nevo E, Sybirna NO. The Effect of the Medicinal Mushrooms Agaricus brasiliensis and Ganoderma lucidum (Higher 
Basidiomycetes) on the Erythron System in Normal and StreptozotocinInduced Diabetic Rats. Int J Med Mushrooms. 2015; 17: 277-286. PubMed: https://pubmed.ncbi.nlm.nih.gov/25954911/

85. Fantuzzi E, Anastácio LR, Nicoli JR, de Paula SO, Arantes RME, et al. Evaluation of Royal Sun Agaricus, Agaricus brasiliensis S. Wasser et al., aqueous extract in mice challenged with Salmonella enterica serovar Typhimurium. Int J Med Mushrooms. 2011; 13: 281-288. PubMed: https://pubmed.ncbi.nlm.nih.gov/22135880/

86. Silva FF, de Oliveira GAC, Costa HCM, Regis WCB. Royal Sun
Culinary-Medicinal Mushroom, Agaricus brasiliensis (Agaricomycetes), Supplement in Training Capacity Improvement Parameters. Int J Med Mushrooms. 2017; 19: 759-766.

PubMed: https://pubmed.ncbi.nlm.nih.gov/29199551/

87. Liu Y, Fukuwatari Y, Okumura K, Takeda K, Ishibashi KI, et al. Immunomodulating Activity of Agaricus brasiliensis KA21 in Mice and in Human Volunteers. Evid Based Complement Alternat Med. 2008; 5: 205-219.

PubMed: https://pubmed.ncbi.nlm.nih.gov/18604247/ 